\title{
Penerapan Metode Pembelajaran Problem Based Learning Dalam Meningkatkan Kemampuan Bercerita Pada Siswa Sekolah Dasar
}

\author{
Husnul Hotimah \\ MIN 2 Jember \\ E-mail : hhotimah42@gmail.com
}

\begin{abstract}
Abstrak
Tugas utama seorang guru adalah bertanggung jawab membantu anak didik dalam hal belajar. Dalam proses belajar mengajar, gurulah yang menyampaikan pelajaran, memecahkan masalah-masalah yang terjadi dalam kelas, membuat evaluasi belajar siswa, baik sebelum, sedang maupun sesudah pelajaran berlangsung. Permasalahan yang ingin dikaji dalam makalah ini adalah apakah metode problem based learning dapat meningkatkan kemampuan siswa dalam bercerita, sedangkan tujuan dari penulisan ini adalah: Untuk mengetahui bahwa metode problem based learning dapat meningkatkan kemampuan siswa dalam bercerita. Kesimpulan dari makalah ini adalah pembelajaran dengan menggunakan metode problem based learning dapat meningkatkan kemampuan siswa dalam bercerita khususnya pada siswa tingkat dasar
\end{abstract}

Kata Kunci : kemampuan bercerita, metode problem based learning, siswa tingkat dasar.

The main task of a teacher is responsible for helping students in terms of learning process, it is the tacher who conveys the lesson, solves the problems that occur in the classroom, evaluates student learning, both before, during and after the lesson. The problem to be studied in this paper is: Is the method of problem based learning can improve students ability to tell stories? While the purpose of this paper is: To know that the method of problem based learning can improve students ability to tell stories. The conclusion of this paper is that learning using problem based learning methods can improve students ability to tell stories especially at elementary level students.

Keywords : ability to tell stories, method of problem based learning, elementary level students.

\section{Pendahuluan}

Dalam upaya peningkatan kualitas sekolah, tenaga kependidikan yang meliputi, tenaga pendidik, pengelola satuan pendidikan, penilik, pengawas, peneliti, teknis sumber belajar, sangat diharapkan berperan sebagaimana mestinya dan sebagai tenaga kependidikan yang berkualitas. Tenaga pendidik yang berkualitas adalah tenaga pendidik yang sanggup, dan terampil dalam melaksanakan tugasnya. Namun kenyataan dilapangan berbeda, banyak di sekolah-sekolah ditemukan guru mengajar tidak sesuai dengan apa yang diharapkan, misalnya mereka mengajar dengan menggunakan metode yang tidak sesuai, media pembelajaran kurang menarik, atau dalam pembelajaran kurang menyenangkan, dan lain sebagainya.

Lukman Ali [1] menjelaskan bahwa metode adalah cara yang teratur dan terpikir baik-baik untuk mencapai maksud, cara kerja yang bersistem untuk memudahkan pelaksanaan suatu kegiatan guna mencapai tujuan yang ditentukan.

Subari mengatakan metodologi pengajaran merupakan cabang dari didaktif atau ilmu mengajar, oleh karena itu sering juga metodologi pengajarn disebut didaktik khusus [2]. Kata metodologi dibentuk dari dua kata yaitu "methodos" yang artinya "jalan ke" sedangkan "logos" berarti "ilmu". Karena itu metodologi pengajaran dapat diartikan suatu ilmu yang memberikan jalan menuju ke terjadinya proses belajar mengajar. Secara umum didaktik khusus atau metologi pengajaran adalah bagian ilmu mengajar yang membicarakan berbagai metode mengajar dan sistem penyampaian bahan pengajaran untuk semua bidang pengajaran serta cara mengajarkan atau menyampaikan bidang pengajaran tertentu.

Dari pendapat diatas diambil kesimpulan bahwa metode pembelajaran adalah suatu cara/tehnik yang dilakukan dalam proses pembelajaran untuk mencapai tujuan dalam pembelajaran.

Problem based learning (PBL) adalah metode pembelajaran yang dipicu oleh permasalahan, yang mendorong siswa untuk belajar dan bekerja kooperatif dalam kelompok untuk mendapatkan solusi, berpikir kritis dan analitis, mampu menetapkan serta menggunakan sumber daya pembelajaran yang sesuai .

Metode PBL / pemecahan masalah adalah suatu cara pembelajaran dengan menghadapkan siswa kepada suatu problem/masalah untuk dipecahkan atau diselesaikan secara konseptual masalah terbuka dalam pembelajaran.

Pemecahan masalah (problem solving) adalah penggunaan metode dalam kegiatan pembelajaran dengan jalan melatih siswa menghadapi berbagai masalah baik itu masalah pribadi atau perorangan maupun masalah kelompok untuk dipecahkan sendiri atau secara bersama-sama. Metode pemecahan masalah (problem solving) juga dikenal dengan metode brainstorming, karena merupakan sebuah metode yang merangsang dan menggunakan wawasan tanpa melihat kualitas pendapat yang disampaikan oleh siswa. Guru disarankan tidak berorientasi pada metode tersebut, akan tetapi guru hanya melihat jalan fikiran yang disampaikan 
oleh siswa, pendapat siswa, serta memotivasi siswa untuk mengeluarkan pendapat mereka, dan sesekali guru tidak boleh tidak menghargai pendapat siswa, sesekalipun pendapat siswa tersebut salah menurut guru.

Problem Based Learning (PBL) merupakan salah satu model pembelajaran yang dapat menolong siswa untuk meningkatkan keterampilan yang dibutuhkan pada pada era globalisasi saat ini. Problem Based Learning (PBL) dikembangkan untuk pertama kali oleh Prof. Howard Barrows sekitar tahun 1970-an dalam pembelajaran ilmu medis di McMaster University Canada [3]. Model pembelajaran ini menyajikan suatu masalah yang nyata bagi siswa sebagai awal pembelajaran kemudian diselesaikan melalui penyelidikan dan diterapkan dengan menggunakan pendekatan pemecahan masalah. (PBL) :

Beberapa definisi tentang Problem Based Learning

1. Menurut Duch, Problem Based Learning (PBL) merupakan model pembelajaran yang menantang siswa untuk "belajar bagaimana belajar", bekerja secara berkelompok untuk mencari solusi dari permasalahan dunia nyata [4]. Masalah ini digunakan untuk mengikat siswa pada rasa ingin tahu pada pembelajaran yang dimaksud.

2. Menurut Arends, Problem Based Learning (PBL) merupakan suatu pendekatan pembelajaran di mana siswa dihadapkan pada masalah autentik (nyata) sehingga diharapkan mereka dapat menyusun pengetahuannya sendiri, menumbuh kembangkan keterampilan tingkat tinggi dan inkuiri, memandirikan siswa, dan meningkatkan kepercayaan dirinya [5]

3. Menurut Glazer, mengemukakan Problem Based Learning merupakan suatu strategi pengajaran dimana siswa secara aktif dihadapkan pada masalah kompleks dalam situasi yang nyata [6].

Dari beberapa uraian mengenai pengertian Problem Based Learning dapat disimpulkan bahwa Problem Based Learning merupakan model pembelajaran yang menghadapkan siswa pada masalah dunia nyata (real world) untuk memulai pembelajaran dan merupakan salah satu model pembelajaran inovatif yang dapat memberikan kondisi belajar aktif kepada siswa. Problem Based Learning adalah pengembangan kurikulum dan proses pembelajaran. Dalam kurikulumnya, dirancang masalah-masalah yang menuntut siswa mendapatkan pengetahuan yang penting, membuat mereka mahir dalam memecahkan masalah, dan memiliki strategi belajar sendiri serta kecakapan berpartisipasi dalam tim. Proses pembelajarannya menggunakan pendekatan yang sistemik untuk memecahkan masalah atau tantangan yang dibutuhkan dalam kehidupan sehari-hari.

Model Problem Based Learning bercirikan penggunaan masalah kehidupan nyata sebagai suatu yang harus dipelajari siswa. Dengan model Problem Based Learning diharapkan siswa mendapatkan lebih banyak kecakapan daripada pengetahuan yang dihafal. Mulai dari kecakapan memecahkan masalah, kecakapan berpikir kritis, kecakapan bekerja dalam kelompok, kecakapan interpersonal dan komunikasi, serta kecakapan pencarian dan pengolahan informasi [7].
Sehingga dapat disimpulkan, bahwa dalam Problem Based Learning pembelajarannya lebih mengutamakan proses belajar, dimana tugas guru harus memfokuskan diri untuk membantu siswa, mencapai keterampilan mengarahkan diri. Guru dalam model ini berperan sebagai penyaji masalah, penanya, mengadakan dialog, membantu menemukan masalah, dan pemberi fasilitas pembelajaran. Selain itu, guru memberikan dukungan yang dapat meningkatkan pertumbuhan inkuiri dan intelektual siswa. Model ini hanya dapat terjadi jika guru dapat menciptakan lingkungan kelas yang terbuka dan membimbing pertukaran gagasan.

Ciri yang paling utama dari model pembelajaran Problem Based Learning yaitu dimunculkannya masalah pada awal pembelajarannya. Menurut Arends [5], berbagai pengembangan pengajaran berdasarkan masalah telah memberikan model pengajaran itu memiliki karakteristik sebagai berikut :

Pengajuan pertanyaan atau masalah

1. Autentik, yaitu masalah harus berakar pada kehidupan dunia nyata siswa dari pada berakar pada prinsip-prinsip disiplin ilmu tertentu.

2. Jelas, yaitu masalah dirumuskan dengan jelas, dalam arti tidak menimbulkan masalah baru bagi siswa yang pada akhirnya menyulitkan penyelesaian siswa.

3. Mudah dipahami, yaitu masalah yang diberikan harusnya mudah dipahami siswa dan disesuaikan dengan tingkat perkembangan siswa.

4. Luas dan sesuai tujuan pembelajaran. Luas artinya masalah tersebut harus mencakup seluruh materi pelajaran yang akan diajarkan sesuai dengan waktu, ruang, dan sumber yang tersedia.

5. Bermanfaat, yaitu masalah tersebut bermanfaat bagi siswa sebagai pemecah masalah dan guru sebagai pembuat masalah.

6. Berfokus pada keterkaitan antar disiplin ilmu Masalah yang diajukan hendaknya melibatkan berbagai disiplin ilmu.

Adapun beberapa karakteristik proses Problem based learning menurut Tan [7] diantaranya :

1. Masalah digunakan sebagai awal pembelajaran.

2. Biasanya, masalah yang digunakan merupakan masalah dunia nyata yang disajikan secara mengambang.

3. Masalah biasanya menuntut perspektif majemuk. Solusinya menuntut siswa menggunakan dan mendapatkan konsep dari beberapa ilmu yang sebelumnya telah diajarkan atau lintas ilmu ke bidang lainnya.

4. Masalah membuat siswa tertantang untuk mendapatkan pembelajaran di ranah pembelajaran yang baru.

5. Sangat mengutamakan belajar mandiri (self directed learning).

6. Memanfaatkan sumber pengetahuan yang bervariasi, tidak dari satu sumber saja.

7. Pembelajarannya kolaboratif, komunikatif, dan kooperatif. Siswa bekerja dalam kelompok, berinteraksi, saling mengajarkan (peer teaching), dan melakukan presentasi.

Dari beberapa penjelasan mengenai karakteristik proses Problem Based Learning dapat disimpulkan bahwa tiga unsur yang esensial dalam proses Problem Based 
Learning yaitu adanya suatu permasalahan, pembelajaran berpusat pada siswa, dan belajar dalam kelompok kecil

Pelaksanaan model Problem Based Learning terdiri dari 5 tahap proses, yaitu :

- Tahap pertama, adalah proses orientasi peserta didik pada masalah. Pada tahap ini guru menjelaskan tujuan pembelajaran, menjelaskan logistik yang diperlukan, memotivasi peserta didik untuk terlibat dalam aktivitas pemecahan masalah, dan mengajukan masalah.

- Tahap kedua, mengorganisasi peserta didik. Pada tahap ini guru membagi peserta didik kedalam kelompok, membantu peserta didik mendefinisikan dan mengorganisasikan tugas belajar yang berhubungan dengan masalah.

- Tahap ketiga, membimbing penyelidikan individu maupun kelompok. Pada tahap ini guru mendorong peserta didik untuk mengumpulkan informasi yang dibutuhkan, melaksanakan eksperimen dan penyelidikan untuk mendapatkan penjelasan dan pemecahan masalah.

- Tahap keempat, mengembangkan dan menyajikan hasil. Pada tahap ini guru membantu peserta didik dalam merencanakan dan menyiapkan laporan, dokumentasi, atau model, dan membantu mereka berbagi tugas dengan sesama temannya.

- Tahap kelima, menganalisis dan mengevaluasi proses dan hasil pemecahan masalah. Pada tahap ini guru membantu peserta didik untuk melakukan refleksi atau evaluasi terhadap proses dan hasil penyelidikan yang mereka lakukan [5].

Kelima tahap yang dilakukan dalam pelaksanaan model

Problem Based Learning ini selengkapnya dapat disimpulkan melalui Tabel 1 di bawah ini

Tabel 1. Tahap-tahap dalam model Problem Based Learning

\begin{tabular}{|c|c|}
\hline menyajikan hasil & $\begin{array}{l}\text { laporan, dokumentasi, atau } \\
\text { model, dan membantu mereka } \\
\text { berbagi tugas dengan sesama } \\
\text { temannya. }\end{array}$ \\
\hline 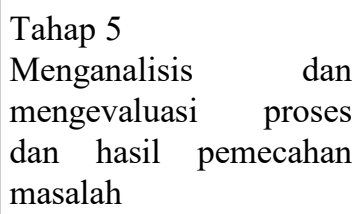 & $\begin{array}{l}\text { Guru membantu siswa untuk } \\
\text { melakukan refleksi atau evaluasi } \\
\text { terhadap proses dan hasil } \\
\text { penyelidikan yang mereka } \\
\text { lakukan }\end{array}$ \\
\hline
\end{tabular}

Sebagai suatu model pembelajaran, Problem Based Learning memiliki beberapa kelebihan, diantaranya :

1. Menantang kemampuan siswa serta memberikan kepuasan untuk menemukan pengetahuan baru bagi siswa.

2. Meningkatakan motivasi dan aktivitas pembelajaran siswa.

3. Membantu siswa dalam mentransfer pengetahuan siswa untuk memahami masalah dunia nyata.

4. Membantu siswa untuk mengembangkan pengetahuan barunya dan bertanggung jawab dalam pembelajaran yang mereka lakukan. Disamping itu, PBM dapat mendorong siswa untuk melakukan evaluasi sendiri baik terhadap hasil maupun proses belajarnya.

5. Mengembangkan kemampuan siswa untuk berpikir kritis dan mengembangkan kemampuan mereka untuk menyesuaikan dengan pengetahuan baru.

6. Memberikan kesempatan bagi siswa untuk mengaplikasikan pengetahuan yang mereka miliki dalam dunia nyata.

7. Mengembangkan minat siswa untuk secaraterus menerus belajar sekalipun belajar pada pendidikan formal telah

\begin{tabular}{|c|c|c|}
\hline & & \\
\hline $\begin{array}{l}\text { Tahap } 1 \\
\text { Orientasi peserta didik } \\
\text { pada masalah }\end{array}$ & $\begin{array}{l}\text { Guru menjelaskan tujuan } \\
\text { pembelajaran, menjelaskan } \\
\text { logistik yang diperlukan, } \\
\text { mengajukan fenomena atau } \\
\text { demonstrasi atau cerita untuk, } \\
\text { memunculkan r masalah, } \\
\text { memotivasi siswa } \\
\text { dalam aktuk terlibat } \\
\text { masalah }\end{array}$ & $\begin{array}{l}\text { yang dipelajari guna memecahkan masalah dunia [8]. } \\
\text { Disamping kelebihan di atas, Problem based learning } \\
\text { juga memiliki kelemahan, diantaranya: } \\
\text { 1. Manakala siswa tidak memiliki minat atau tidak } \\
\text { mempunyai kepercayaan bahwa masalah yang dipelajari } \\
\text { sulit untuk dipecahkan, maka mereka akan merasa } \\
\text { enggan untuk mencobanya. } \\
\text { 2. Untuk sebagian siswa beranggapan bahwa tanpa } \\
\text { pemahaman mengenai materi yang diperlukan untuk }\end{array}$ \\
\hline $\begin{array}{l}\text { Tahap } 2 \\
\text { Mengorganisasi peserta } \\
\text { Didik }\end{array}$ & $\begin{array}{l}\text { Guru membagi siswa ke dalam } \\
\text { kelompok, membantu siswa } \\
\text { mendefinisikan } r \text { dan } \\
\text { mengorganisasikan tugas belajar } \\
\text { yang berhubungan dengan } \\
\text { masalah. }\end{array}$ & $\begin{array}{l}\text { untuk memecahkan masalah yang sedang dipelajari, } \\
\text { maka mereka akan belajar apa yang mereka ingin } \\
\text { pelajari [8]. } \\
\text { Dapat disimpulkan bahwa dari beberapa kelebihan dan } \\
\text { kelemahan model pembelajaran problem based learning ini } \\
\text { di neroleh beberana nilai nokok vang harus dikembanokan }\end{array}$ \\
\hline $\begin{array}{l}\text { Tahap } 3 \\
\text { Membimbing } \\
\text { penyelidikan individu } \\
\text { maupun kelompok }\end{array}$ & $\begin{array}{l}\text { Guru mendorong peserta didik } \\
\text { untuk mengumpulkan informasi } \\
\text { yang dibutuhkan, melaksanakan } \\
\text { eksperimen dan penyelidikan } \\
\text { untuk mendapatkan penjelasan } \\
\text { dan pemecahan masalah }\end{array}$ & $\begin{array}{l}\text { oleh guru dalam menghidupkan suasana pembelajaran ,disini } \\
\text { guru tidak hanya berperan sebagai subjek utama dalam } \\
\text { pembelajaran tapi disisi lain guru harus melibatkan siswa } \\
\text { agar kemampuan berfikir kritis siswa dapat berkembang } \\
\text { walaupun masih saja dapat di nilai tidak semua materi } \\
\text { pelajaran dapat di sajikan dalam bentuk permasalahn untuk }\end{array}$ \\
\hline $\begin{array}{l}\text { Tahap } 4 \\
\text { Mengembangkan }\end{array}$ & $\begin{array}{l}\text { Guru membantu siswa dalam } \\
\text { merencanakan dan menyiapkan }\end{array}$ & $\begin{array}{l}\text { penyelesaian tapi setidaknya dengan bekerja } \\
\text { nenumbuh kembnagkan minat dan bakat peserta } \\
\text { tidak langsung. }\end{array}$ \\
\hline
\end{tabular}

8. Memudahkan siswa dalam menguasai konsep-konsep yang dipelajari guna memecahkan masalah dunia [8]. 
Hasil belajar adalah kemampuan yang dimiliki siswa setelah melakukan proses pembelajaran yang ditandai oleh perubahan tingkah laku dan dapat diukur melalui tes yang dapat ditunjukkan berupa angka atau nilai. Hal ini sesuai dengan pendapat Dimyati [9] bahwa untuk memperoleh informasi tentang baik atau buruknya prose dan hasil kegiatan pembelajaran maka seorang guru harus menyelenggarakan evaluasi. Menurut pendapat Sujana hasil belajar adalah kemampuan yang dimiliki oleh siswa setelah ia menerima pengalaman belajarnya, atau pada hakekatnya hasil belajar biasanya ditunjukkan berupa nilai atau angka. Jadi hasil belajar siswa dapat diketahui melalui penilaian dan evaluasi.

Menurut Abdullah [10] bahwa hasil belajar merupakan indikator kualitas dari pengatahuan yang telah dikuasai oleh siswa. Di sisi lain hasil belajar siswa merupakan hasil dari suatu sistem pendidikan, sehingga tingkat keberhasilannya ditentukan oleh elemen-elemen dalam sistem itu sendiri, seperti : motivasi siswa sebagai raw input, dan peranan guru sebagai instrumen input.

Sekolah sebagai salah satu sistem pendidikan secara formal membentuk subjek didik (siswa) untuk meningkatkan prestasi belajar melalui proses belajar mengajar. Hasil belajar merupakan salah satu ukur untuk memahami tingkat keberhasilan seorang siswa dalam kegiatan proses belajar mengajar yang diikutinya di sekolah. Dengan demikian, prestasi belajar seorang siswa dapat ditandai dari hasil belajar dalam batas ranking tertentu. Batasan ranking tersebut, dapat dijadikan ukuran penentuan keberhasilan siswa setelah mengikuti proses pendidikan di sekolah .Misalnya, naik kelas ,tidak naik kelas atau kelulusan siswa dapat ditentukan dari hasil belajarnya. Dalam kamus umum Fikih (1976),kata "prestasi" diartikan sebagai hasil yang dicapai. Senada dengan pendapat Djamarah, bahwa prestasi diartikan sebagai hasil dari suatu kegiatan yang telah dikerjakan dan diciptakan baik secara individual maupun kelompok [11].

Berdasarkan batasan pengertian hasil belajar tersebut, dapat disimpulkan bahwa hasil belajar pada dasarnya merupakan hasil yang telah dicapai oleh siswa melalui kegiatan belajar. Kegiatan belajar dapat dilakukan secara individu dan atau secara kelompok. Jadi,hasil belajar paling tidak memiliki dua ciri, yaitu adanya suatu tindakan (action) baik yang dilikukan secara individu dan atau secara kelompok serta adanya suatu hasil (output).

Tingkat hasil belajar yang dicapai oleh siswa di sekolah tidak tumbuh dan berkembang begitu saja, akan tetapi merupakan suatu hasil proses interaksi dari berbagai faktor yang mempengaruhinya. Slameto membagi faktorfaktor yang mempengaruhi hasil belajar itu , dapat bersifat eksternal dan bersifat internal [12]. Faktor eksternal ,yaitu keadaan di luar diri siswa yang meliputi : kondisi keluarga, sekolah, dan masyarakat. Faktor internal, yaitu keadaan diri siswa yang meliputi keadaan fisik, dan psikologis termasuk kelemahan baik fisik maupun psikis. Kaitannya dengan faktor internal, kondisi psikologis memiliki peranan yang penting mengingat bahwa belajar merupakan proses mental yang berpengaruh terhadap hasil belajar siswa meliputi : minat, kecerdasan, bakat, motivasi, dan kemampuan kognitif.
Berdasarkan uraian tersebut, tampak bahwa faktorfaktor yang menentukan hasil belajar adalah sangat kompleks. Menurut Clark hasil belajar siswa di sekolah 70\% dipengaruhi oleh kemampuan siswa sendiri dan $30 \%$ dipengaruhi oleh lingkungan [13]. Sejalan dengan tinjauan tentang faktor- faktor yang mempengaruhi hasil belajar siswa tersebut, maka dapat disimpulkan bahwa hasil belajar siswa di sekolah ditentukan oleh faktor- faktor yang bersifat endogen atau internal siswa itu sendiri seperti motivasi belajar siswa dan faktor eksogen atau eksternal siswa seperti peranan guru dalam proses belajar mengajar. Merujuk pada uraian latar belakang di atas, dapat dikaji ada beberapa permasalahan yang dirumuskan "Apakah melalui metode problem based learning dapat meningkatkan kemampuan siswa dalam bercerita?".

\section{Metode Penelitian}

Metode penelitian yang kami lakukan adalah penelitian tindakan (action research), karena penelitian dilakukan untuk memecahkan masalah pembelajaran di kelas. Penelitian ini juga termasuk penelitian deskriptif, sebab menggambarkan bagaimana suatu teknik pembelajaran diterapkan dan bagaimana hasil yang diinginkan dapat dicapai.

Menurut Sukidin dkk ada 4 macam bentuk penelitian tindakan, yaitu: (1) penelitian tindakan guru sebagai peneliti, (2) penelitian tindakan kolaboratif, (3) penelitian tindakan simultan terintegratif, dan (4) penelitian tindakan sosial eksperimental

Keempat bentuk penelitian tindakan di atas, ada persamaan dan perbedaannya. Menurut Oja dan Smulyan sebagaimana dikutip oleh Kasbolah, , ciri-ciri dari setiap penelitian tergantung pada: (1) tujuan utamanya atau pada tekanannya, (2) tingkat kolaborasi antara pelaku peneliti dan peneliti dari luar, (3) proses yang digunakan dalam melakukan penelitian, dan (4) hubungan antara proyek dengan sekolah.

Dalam penelitian ini menggunakan bentuk guru sebagai peneliti, dimana guru sangat berperan sekali dalam proses penelitian tindakan kelas, sedangkan aktivitas pengamatan dilakukan oleh guru lain. Tujuan utama penelitian tindakan kelas ini ialah untuk meningkatkan praktik-praktik pembelajaran di kelas. Dalam kegiatan ini, guru terlibat langsung secara penuh dalam proses perencanaan, tindakan, observasi, dan refleksi. Kehadiran pihak lain dalam penelitian ini peranannya tidak dominan dan sangat kecil.

Penelitian ini mengacu pada perbaikan pembelajaran yang berkesinambungan. Model penelitian tindakan adalah berbentuk spiral. Tahapan penelitian tindakan pada suatu siklus meliputi perencanaan atau pelaksanaan observasi dan refleksi. Siklus ini berlanjut dan akan dihentikan jika sesuai dengan kebutuhan dan dirasa sudah cukup.

Menurut pengertiannya penelitian tindakan adalah penelitian tentang hal-hal yang terjadi dimasyarakat atau sekolompok sasaran, dan hasilnya langsung dapat dikenakan pada masyarakat yang bersangkutan. Ciri atau karakteristik utama dalam penelitian tindakan adalah adanya partisipasi dan kolaborasi antara peneliti dengan anggota kelompok sasaran. Penelitian tidakan adalah satu strategi pemecahan 
masalah yang memanfaatkan tindakan nyata dalam bentuk proses pengembangan invovatif yang dicoba sambil jalan dalam mendeteksi dan memecahkan masalah. Dalam prosesnya pihak-pihak yang terlibat dalam kegiatan tersebut dapat saling mendukung satu sama lain.

Sedangkan tujuan penelitian tindakan harus memenuhi beberapa prinsip sebagai berikut:

1. Permasalahan atau topik yang dipilih harus memenuhi kriteria, yaitu benar-benar nyata dan penting, menarik perhatian dan mampu ditangani serta dalam jangkauan kewenangan peneliti untuk melakukan perubahan.

2. Kegiatan penelitian, baik intervensi maupun pengamatan yang dilakukan tidak boleh sampai mengganggu atau menghambat kegiatan utama.

3. Jenis intervensi yang dicobakan harus efektif dan efisien, artinya terpilih dengan tepat sasaran dan tidak memboroskan waktu, dana dan tenaga.

4. Metodologi yang digunakan harus jelas, rinci, dan terbuka, setiap langkah dari tindakan dirumuskan dengan tegas sehingga orang yang berminat terhadap penelitian tersebut dapat mengecek setiap hipotesis pembuktiannya.

5. Kegiatan penelitian diharapkan dapat merupakan proses kegiatan yang berkelanjutan (on-going), mengingat bahwa pengembangan dan perbaikan terhadap kualitas tindakan memang tidak dapat berhenti tetapi menjadi tantangan sepanjang waktu.

Sesuai dengan jenis penelitian yang dipilih, yaitu penelitian tindakan, maka penelitian ini menggunakan model penelitian tindakan dari Kemmis dan Taggart yaitu berbentuk spiral dari siklus yang satu ke siklus yang berikutnya. Setiap siklus meliputi planning (rencana), action (tindakan), observation (pengamatan), dan reflection (refleksi). Langkah pada siklus berikutnya adalah perncanaan yang sudah direvisi, tindakan, pengamatan, dan refleksi. Sebelum masuk pada siklus 1 dilakukan tindakan pendahuluan yang berupa identifikasi permasalahan.

$$
\text { Penelitian ini dilaksanakan }
$$$$
\text { selama }
$$
putaran 1 , dan 2 , dimana masing-masing putaran dikenai perlakuan yang sama (alur kegiatan yang sama) dan membahas satu sub pokok bahasan yang diakhiri dengan tes formatif di akhir masing-masing putaran. Dibuat dalam dua putaran dimaksudkan untuk memperbaiki sistem pengajaran yang telah dilaksanakan.

Tempat penelitian adalah tempat yang digunakan dalam melakukan penelitian untuk memperoleh data yang diinginkan. Penelitian ini bertempat di kelas 1a MIN 2 Jember. Waktu penelitian adalah waktu berlangsungnya penelitian atau saat penelitian ini dilangsungkan. Penelitian ini dilaksanakan pada bulan Pebruari semester genap 2019/2020. Subyek penelitian adalah siswa-siswi Kelas Ia MIN 2 Jember tahun pelajaran 2019/2020 yang berjumlah 28 siswa pada pokok bahasan bercerita tentang diri dan keluarga.

Penelitian ini dilakukan melalui tiga tahap, yaitu: (1) tahap persiapan, (2) tahap pelaksanaan, dan (3) tahap penyelesaian. Kegiatan yang dilakukan dalam tahap persiapan ini adalah mempersiapkan segala sesuatu yang berhubungan dengan pelaksanaan penelitian. Dalam kegiatan ini diharapkan pelaksanaan penelitian akan berjalan lancar dan mencapai tujuan yang diinginkan. Kegiatan persiapan ini meliputi:(1) kajian pustaka, (2) pengurusan administrasi perijinan, (3) penyusunan rancangan penelitian, (4) orientasi lapangan, dan (5) penyusunan instrumen penelitian. Pada tahap pelaksanaan penelitian ini, kegiatan yang dilakukan meliputi:(1) pengumpulan data melalui tes dan pengamatan yang dilakukan persiklus, (2) diskusi dengan pengamat untuk memecahkan kekurangan dan kelemahan selama proses belajar mengajar persiklus, (3) menganalisi data hasil penelitian persiklus, (4) menafsirkan hasil analisis data, dan (5) bersama-sama dengan pengamat menentukan langkah perbaikan untuk siklus berikutnya. Dalam tahap penyelesaian, kegiatan yang dilakukan meliputi:(1) menyusun draf laporan penelitian, (2) mendiskusikan draf laporan penelitian, (3) merevisi draf laporan penelitian, (4) menyusun naskah laporan penelitian, dan (5) menggandakan laporan penelitian.

\section{Hasil dan Pembahasan}

Dari hasil pengamatan pada kegiatan bercerita yang diberikan pada siswa kelas I MI Negeri 2 Jember yang berjumlah 28 siswa, sebanyak 16 anak atau sekitar 57\% tidak mampu bercerita (belum terlihat), sedang yang mampu bercerita berjumlah 12 anak atau sekitar $43 \%$. Hal tersebut diketahui permasalahannya yaitu bahwa mereka memang tidak berani bercerita karena malu atau mereka tidak mampu bercerita karena sebab-sebab tertentu. Bercerita merupakan kegiatan berbahasa/yang bersifat produktif. Artinya, dalam bercerita seseorang melibatkan pikiran, kesiapan mental, keberanian, perkataan yang jelas sehingga dapat dipahami oleh orang lain. Menurut Burhan Nurgiyantoro [14], ada beberapa bentuk tugas kegiatan berbicara yang dapat dilatih untuk meningkatkan dan mengembangkan keterampilan bercerita pada siswa, yaitu (1) bercerita berdasarkan gambar, (2) wawancara, (3) bercakap-cakap, (4) berpidato, (5) berdiskusi.

Keterampilan Berbicara (Speaking) sangat identik dengan bercerita. Tarigan mendefinisikan keterampilan berbicara sebagai kemampuan mengungkapkan bunyi-bunyi artikulasi atau kata-kata untuk mengekspresikan [15]. Hornby mendefinisikan berbicara (speaking), sebagai”to talk to somebody about something,to have a conversation with somebody". Jadi, berbicara adalah sebuah kegiatan yang dilakukan seseorang kepada orang lain tentang suatu hal atau kegiatan percakapan yang dilakukan seseorang kepada orang lain. Bercerita merupakan salah satu kebiasaan masyarakat sejak dahulu sampai sekarang. Hampir setiap siswa yang telah menikmati suatu cerita akan selalu siap untuk menceritakannya kembali, terutama jika cerita tersebut mengesankan bagi siswa. Ada dua unsur penting yang harus dikuasai siswa dalam bercerita yaitu linguistik dan unsur apa yang diceritakan. Ketepatan ucapan, tata bahasa, kosakata, kefasihan dan kelancaran, menggambarkan bahwa siswa memiliki kemampuan berbicara yang baik.

Keterampilan bercerita yang baik memerlukan pengetahuan, pengalaman serta kemampuan berpikir yang memadai.Selain itu dalam bercerita juga diperlukan penguasaan beberapa keterampilan, yaitu ketepatan 
tatabahasa sehingga hubungan antar kata dan kalimat menjadi jelas. Ketepatan kata dan kalimat sangat perlu dikuasai dalam bercerita, sebab dengan menggunakan kata dan kalimat yang tepat dalam bercerita akan memudahkan pendengar memahami isi cerita yang dikemukakan oleh pembicara. Isi cerita yang mudah dipahami akan menunjang dalam penyampaian maksud yang sama antara pembicara dan pendengar, sehingga tujuan penyampaian makna cerita juga dapat tercapai. Selain itu dalam bercerita diperlukan kelancaran dalam menyampaikan kalimat per kalimat. Kelancaran dalam menyampaikan isi cerita akan menunjang pembicara dalam menyampaikan isi cerita secara runtut dan lancar sehingga penyimak/ pendengar yang mendengarkan dapat antusias dan tertarik mendengarkan cerita.

Berdasarkan uraian di atas, dapat disimpulkan bahwa untuk mengembangkan keterampilan bercerita seseorang harus mampu memperhatikan tatabahasa yang digunakan termasuk ketepatan kata dan kalimat.Selain itu perlu diperhatikan kelancaran dalam penyampaian kalimat dalam cerita.

Pada dasarnya, tujuan utama dari bercerita adalah untuk berkomunikasi atau bertukar informasi dengan orang lain. Agar dapat menyampaikan pikiran secara efektif, seorang yang bercerita harus memahami makna segala sesuatu yang ingin dikomunikasikan. Hal ini sejalan dengan pendapat Burhan Nurgiyantoro yang mengemukakan bahwa tujuan bercerita adalah untuk mengemukakan sesuatu kepada orang lain [14].

Sementara itu, Tarigan [16] mengungkapkan tiga tujuan umum dari kegiatan bercerita yaitu sebagai berikut:

a) Memberitahukan dan melaporkan (to inform)

b) Menjamu dan menghibur (to entertain)

c) Membujuk, mengajak, mendesak, dan meyakinkan (to persuade).

Dari penjelasan yang telah dikemukakan di atas, maka dapat diambil kesimpulan bahwa tujuan dari kegiataan bercerita adalah untuk berkomunikasi dengan orang lain dengan cara melaporkan, membujuk, meyakinkan.

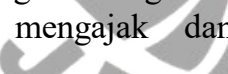

Tadkiroatun Musfiroh [17] ditinjau dari beberapa aspek, menyatakan bahwa manfaat bercerita, adalah sebagai berikut:

a) Membantu pembentukan pribadi dan moral anak

b) Menyalurkan kebutuhan imajinasi dan fantasi

c) Memacu kemampuan verbal anak

d) Merangsang minat menulis anak

e) Membuka cakrawala pengetahuan anak

Sedangkan, Bachtiar S. Bachri mengatakan bahwa manfaat bercerita adalah dapat memperluas wawasan dan cara berfikir anak, sebab dalam bercerita anak mendapat tambahan pengalaman yang bisa jadi merupakan hal baru baginya.

Semua permasalahan pasti ada penyebabnya, begitu juga ketidak mampuan siswa dalam bercerita pasti ada sebab-sebab yang menjadikan anak tidak berminat atau tidak suka mengikuti pelajaran bercerita tersebut. Setelah dianalisa permasalahan tersebut disebabkan guru dalam menyampaikan materi kurang menyenangkan, dan media pembelajarannya juga kurang menarik, sehingga siswa kurang berminat mengikuti pembelajaran khususnya materi bercerita. Hal ini diperkuat oleh pendapat Baharuddin (Kompas) "Bila proses pembelajaran tidak bisa memberikan rasa nyaman maka keberhasilan anak untuk belajar sudah terkurangi 50\%". Oleh karena itu model pembelajaran seperti itu seharusnya sudah ditinggalkan dan tidak lagi digunakan dalam proses pembelajaran karena sudah tidak sesuai dengan perkembangan anak dan tuntutan zaman.

Agar proses pembelajaran Tematik dapat berlangsung secara aktif, inovatif, kreatif, efektif dan menyenangkan (PAKEM), maka proses pembelajaran harus dibangun berdasarkan kegembiraan siswa dan guru. Oleh karena salah satu metode yang diharapkan dapat meningkatkan proses pembelajaran khususnya kemampuan bercerita adalah "problem based learning", maka perlu dilakukan penelitian sederhana di kelas berupa Penelitian Tindakan Kelas (PTK) pada siswa kelas I MI Negeri 2 Jember dalam pembelajaran tematik khususnya pada indikator siswa dapat menceritakan pengalamannya atau kegiatannya bersama keluarga di rumah.

Problem Based Learning merupakan salah satu metode pembelajaran yang digunakan dalam proses belajar mengajar khususnya pada keterampilan bercakap-cakap atau bercerita. Metode PBL ini dilakukan dalam kelas kecil, síswa diberikan kasus untuk menstimulasi diskusi kelompok. Kemudian siswa mwngutarakan hasil pencarian materi terkait kasus dan didiskusikan dalam kelompok. Kebaikan metode problem based learning diantaranya adalah: 1) Siswa menjadi lebih aktif dalam mencari materi atau informasi terkait kasus. 2) Siswa aktif dalam menyampaikan pendapat dan berdiskusi. 3) Suasana kelas tidak membosankan dan menyita fokus siswa.

\section{Kesimpulan dan Saran}

Dari pembahasan dapat ditarik beberapa kesimpulan melalui metode problem based learning dapat meningkatkan kemampuan siswa dalam bercerita. Dalam pembelajaran bercerita, problem based learning dikembangakan diskusi dan komunikasi dengan tujuan agar siswa saling berbagi kemampuan, saling belajar berpikir kritis, saling menyampaikan pendapat, saling memberi kesempatan menyalurkan kemampuan, saling membantu belajar, saling menilai kemampuan dan peranan diri sendiri maupun teman lain.

Saran yang ingin dikemukakan melalui tulisan ini bagi guru,metode problem based learning dapat dijadikan sebagai alternatif bagi guru untuk diterapkan dalam pembelajaran di kelas khususnya materi bercerita. Agar kegiatan belajar mengajar berjalan efektif, maka guru harus mampu memilih metode mengajar yang paling sesuai. Proses pembelajaran akan efektif jika berlangsung dalam situasi dan kondisi yang kondusif, hangat, menarik, menyenangkan, dan wajar. Oleh karena itu guru perlu memahami berbagai metode mengajar dengan berbagai karakteristiknya, sehingga mampu memilih metode yang tepat dan mampu menggunakan metode mengajar yang bervariasi sesuai dengan tujuan maupun kompetensi yang diharapkan. Bagi kepala madrasah,diharapkan mau menciptakan kondisi yang merangsang para guru untuk aktif dalam melaksanakan 
kegiatan kreatif dan apresiatif di sekolah maupun di lingkungan sekolah.

\section{References}

[1] Ali Lukman, Kamus Besar Bahasa Indonesia, Perum Balai Pustaka, Jakarta, 1995.

[2] Subari, Supervisi Pendidikan Dalam Rangka Perbaikan Situasi Mengajar, Bumi Aksara, Jakarta, 1994.

[3] Amir, M Taufiq, Inovasi Pendidikan Melalui Problem Based Learning, Kencana Prenada Media Group, Jakarta, 2009.

[4] Duch, Belajar dan Pembelajaran, Rineka Cipta, Jakarta, 1995.

[5] Trianto, Mendesain Model Pembelajaran Inovatif Progresif, Kencana, Jakarta, 2009

[6] E. Glazer, Problem Based Instruktion , In M.Orey (Ed), Emerging perspektives on learning, teaching, and technology, (2001). http://www.coe.uga.edu/epltt/ProblemBasedInstruct.htm.

[7] T. Amir, KarakteristikProses Pembelajaran Berbasis Masalah, PT Prestasi Pustakarya, Jakarta, 2007.

[8] W. Sanjaya, WSanjaya, Strategi pembelajaran berorientasi standar proses pendidikan, Kencana, Jakarta, 2007.

[9] Dimyati dan Mudjiono, Belajar dan Pembelajaran, PT Rineka Cipta, Jakarta, 1999.

[10] A. Abdullah, T \& Suryomiharjo, Ilmu Sejarah dan Historografi Arah dan Perspektif, Gramedia, Jakarta, 1985.

[11] S.. Djamarah, Prestasi Belajar dan Kompetensi Guru, Usaha Nasional, Surabaya, 1994.

[12] Slameto, Belajar dan Factor Yang Mempengaruhinya, Rineka Cipta, Jakarta, 1991.

[13] H. da. E.F.C. Clark, psychology and language, Harcourt Brace, London, 1997.

[14] N. Burhan, Penelitian dalam Pengajaran Bahasa dan Sastra, BPFE Yokyakarta, Yogyakarta, 2001.

[15] Tarigan, Pendidikan Keterampilan Berbahasa, Universitas Terbuka, Jakarta, 2008.

[16] Tarigan, Menyimak: Sebagai Suatu Keterampilan Berbahasa Angkasa, Bandung, 1981.

[17] T. Musfiroh, Bercerita Untuk Anak Usia Dini, Departemen Pendidikan Nasional, Jakarta, 2005. 